\title{
A sustainable future for corporate governance theory and practice
}

\author{
Shann Turnbull ${ }^{*}$ \\ International Institute for self-governance
}

\begin{tabular}{|c|c|}
\hline AB S TRACT & ARTICLE INFO \\
\hline $\begin{array}{l}\text { With this paper we show how the natural "science of control and } \\
\text { communications in the animal and the machine" identified by Wiener in } \\
1948 \text { can be applied to social organizations to establish a science of } \\
\text { governance. Evidence is provided that current practices are not } \\
\text { consistent with the laws of nature or the practices of living things that } \\
\text { must become self-regulating and self-governing to exist in dynamic } \\
\text { unknowable complex environments. Case studies of stakeholder mutual } \\
\text { firms with hundreds of boards show how an ecological form of } \\
\text { polycentric decision-making provides: (a) division of powers; (b) checks } \\
\text { and balances; (c) distributed intelligence to reduce information overload, } \\
\text { and (d) decomposition of decision-making labour to introduce tensions } \\
\text { of challenge; (e) a requisite variety of cross checking communication } \\
\text { and control channels from stakeholder engagement to improve their } \\
\text { integrity; (f) integration of management and governance to further self- } \\
\text { regulation and self-governance with: (g) operating advantages such as } \\
\text { resiliency, sustainability and wellbeing for firm, its stakeholders and } \\
\text { society. The case studies illustrate how ecological governance could } \\
\text { reduce the size, scope, cost and intrusiveness of government and their } \\
\text { regulators while improving economic efficiency and enriching } \\
\text { democracy with widespread citizen stakeholder engagement. }\end{array}$ & $\begin{array}{l}\text { Keywords: } \\
\text { Byte analysis; Chaordic } \\
\text { organizations; Corporate } \\
\text { governance; Firm } \\
\text { performance; Governance } \\
\text { science; Holarchy; Multiple } \\
\text { boards; Polycentric } \\
\text { governance; Risk } \\
\text { management; Tensegrity } \\
\text { *Corresponding author: } \\
\text { sturnbull@alumni.harvard.edu }\end{array}$ \\
\hline
\end{tabular}

\section{INTRODUCTION}

This paper shows how the natural "science of control and communications in the animal and the machine" identified and described by Wiener (1948) as "cybernetics" can be applied to social organizations to establish a science of governance. The science of governance explains how smallbrained creatures with little intelligence can sustain their existence in complex, unknowable dynamic environments while corporations governed by large brained highly intelligent humans cannot.

Adoption of the science of governance provides a basis for achieving a sustainable future for corporate governance theory and practice. However, it means discarding some so called "best governance" practices and turning others upside down. This is because all creatures including humans sustain their existence from augmenting internal top down control and communication channels with bottom up and other channels to create an "ecological" form of "network governance" (Turnbull 2002a). 
Network governance arises when a network of boards, and/or control centers internal and/or external to an organization governs its operations. This definition extends the one proposed by Jones, Hesterly \& Borgatti (1997) who did not consider the possibility of a division of power occuring within an organisation to create an internal network of control centers to introduce distributed intelligence. Their defintion was limited to networks of firms. This created the problem of identifying the boundaries of firms as raised by Zingales (2000).

Highly successful examples of network governed organisations with over a hundred boards are provided by the John Lewis Partnership in the United Kingdom, VISA International located in the US and the nested networks of networked stakeholder cooperatives located around the town of Mondragon in Spain. Their existance indicates that the introduction of network governance need not necessarily require any change in the law.

Without the introduction of a division of power within an organisation it is not possible to introduce a special type of "ecological" or "holonic" network governance found univerally in social animals (Dunbar 1993). Ecological governance is based on decentralisation as found in the human brain to allow redundancy and so resiliency. As noted by Kurzweil (1999: 84) "None of our individual brain cells is all that important - there is no Chief Executive Officer neuron".

A fundamental requirement of creatures to exist over generations is the ability to sustain their existance for sufficient time to reproduce themselves in complex, unknowable dynamic environments. To achieve this objective creatures need to be self-regulating and for their social groups to be self-governing.

The ability of firms to become self-regulating would reduce the cost, size and intrusiveness of government and their regulators. For this reason and to follow the imperatives and precendents in the evolution of living things, good governance will be defined as the ability of organisations to further their self-governance. To become self-governing, firms need to become self-regulating to high degree. In this way the regulation of firms becomes largley privatised. Ecological governance becomes a part of "networked regulation" (Tomasic \& Akinbami 2011: 242). Offsetting the additional costs of introducing self-regulation and self-governance there are operating and competitive advantages as identified in section four. Operational efficiency is of little importance for a creature or firm that cannot survive.

PAGE 2| Journal of Corporate Governance, Insurance, and Risk Management | 2017, VOL. 4, Series. 2 
A practical compelling reason for large complex organisations to adopt ecological governance is provided by the experience of Japanese robot manufacturers. "The reduction in data transmission, and in data complexity, achieved by holonic architecture is prodigeous. Moreover the advantages accumulate as the robotic device gets more complicated." (Mathews 1996: 30). In other words ecological governance allows the data processing by executives and/or board members to be prodigeiously reduced to reduce the risk of physiological and/or neurologcial overloading. There are many additional advantages of ecological governance described in the following sections.

To fully appreciate the advantages of ecological governance an introduction to the science of governance is required. This is undertaken in the following section two. The third section considers how and why so called "best" or "good" governance practices have failed. Section four illustrates network governance with its benefits for various stakeholders outlined in section five. The concluding section six outlines the irrelevancy of dominant corporate governance theories and practices.

\section{THE SCIENCE OF GOVERNANCE}

Stafford Beer pioneered the application of cybernetics principles to management that became described variously as "operations research", "management cybernetics", "management science" or "system science". As the President of the World Organization of System Science and Cybernetics, Beer informed me in 1996 that neither he nor his colleagues had applied the science of control and communications to the governance of organizations.

From 1970 to 1973 Beer had worked for President Allende in Chile to establish a system of control and communications to operate a socialist economy using Teletype printers. So while Beer had applied the principals of cybernetics to coordinating firms this had been achieved in top down control and communication system as commonly found in hierarchical firms. One widely known contribution of Beer (1985) was his concept of organizing units of a firm into a "viable system" to efficaciously manage complex tasks. This contribution was based on conceptual rather than quantitative cybernetic analysis.

Quantitative analysis of organizations only became possible when technology progressed to allow natural scientists to identify the physiological and neurological limits of individuals to receive, store, process and transmit data. Organizational theorists have long recognized data processing as a fundamental problem. Williamson (1979: note 4) stated: "But for the limited ability of human agents to receive, store, retrieve, and process data, interesting economic 
problems vanish". "The problem of organization is precisely one of decomposing the enterprise in efficient informational processing” (Williamson 1985: 283).

Quantifying the ability of humans to receive, store, process and transmit data was only achieved at the turn of the last century. The then head of the British Telecom Research Laboratories Peter Cochrane (2000) quantified the physiological limits of individuals to receive and transmit data in terms of bytes as is set in Figure 1. MIT based voice recognition scientist Ray Kurzweil (1999: 103) reported the limitations of the human brain to sequentially process data in terms of bytes as noted in the centre of Figure 1. He explains how humans overwhelmingly solve problems by pattern recognition. Kurzweil (1999: 79) points out that when ten-year old girl goes to catch a ball "it follows a path that can be predicted from the ball's initial trajectory, spin, and speed, as well as wind conditions.” Calculation of where to go to catch the ball "would appear to require the solution of an overwhelming set of complex simultaneous equations." These equations need to be constantly recomputed as a new visual data streams in”. The point is that humans achieve complex tasks through pattern recognition developed through trial and error until the skill becomes innate not requiring conscious data processing. Driving a car is an example. Pattern recognition skills provide a rationale for business schools to educate through the case method so as to provide synthetic experiences.

The human brain is a massively parallel computer processing many bits of data at once rather than one bit at time as undertaken by personal computers at the time Kurzweil was writing in 1999. As a result, the personal computer at that time could only "emulate about a million neuron connection calculations per second, which is more than a billion times slower than the human brain” (Kurzweil 1999: 79). Like catching a ball, humans recognized faces and voices by data pattern recognition. This is why voice recognition has taken time for computers to catch up to the capabilities of the human brain.

It has now become common for all the data provided to board members to be in digital form. This allows the quantity of data received by each board member to be quantified. The time involved for its input can also be measured to identify data overload. With the use of content analysis estimates of information over load can also be obtained. Technology now makes it possible to use data measured in bits and bytes to become a unit of organizational analysis. Both Williamson (1990: xi) and Simon (1984: 40) saw the need "for observing the phenomena at a higher level of resolution". Bytes provide an answer in this regard and also answer the question raised by Williamson (1990: xi) "how micro is micro?" 


\begin{tabular}{|c|c|c|c|c|c|c|c|}
\hline \multirow{3}{*}{$\begin{array}{l}\text { Capacity in } \\
\text { bytes/sec }\end{array}$} & \multicolumn{6}{|c|}{ Human input data channels ${ }^{a}$} & \multirow{3}{*}{$\begin{array}{l}\text { Constraints in humans to } \\
\text { transact bytes created by: }\end{array}$} \\
\hline & \multicolumn{2}{|c|}{ Smell } & Taste & Touch & Sound & Sight & \\
\hline & \multicolumn{2}{|c|}{$<10 K^{b}$} & $<15 K^{b}$ & $<15 \mathrm{~K}^{\mathrm{b}}$ & $100 K^{b}$ & $1,000 M^{b}$ & \\
\hline \multirow{5}{*}{$\begin{array}{c}\text { Nature of } \\
\text { transacting } \\
\text { bytes in } \\
\text { humans }\end{array}$} & 1 & \multicolumn{5}{|c|}{ Reception through organs } & Physiology \\
\hline & 2 & \multicolumn{5}{|c|}{ Storage through nervous system } & Physiology \\
\hline & 3 & \multicolumn{5}{|c|}{$\begin{array}{l}\text { Perception/understanding through the activation and } \\
\text { strengthening of neural networks which correlate } \\
\text { current patterns with previous ones }\end{array}$} & $\begin{array}{l}\text { Physiology plus experience, } \\
\text { training and motivation }\end{array}$ \\
\hline & 4 & \multicolumn{5}{|c|}{$\begin{array}{l}\text { Insight/knowledge through sequential processing in } \\
\text { neo-cortex limited to around } 200 \text { calculations per/sec } \\
\text { (Kurzweil 1999: 103) }\end{array}$} & $\begin{array}{l}\text { As above plus size and } \\
\text { architecture of neo-cortex } \\
\text { and psychological status }\end{array}$ \\
\hline & 5 & \multicolumn{5}{|c|}{$\begin{array}{l}\text { External responses transmitted by movement and } \\
\qquad \text { vocal chords }\end{array}$} & $\begin{array}{l}\text { Proximity/distance, } \\
\text { environmental conditions, } \\
\text { culture, literacy \& numeracy }\end{array}$ \\
\hline \multirow{3}{*}{$\begin{array}{l}\text { Capacity in } \\
\text { bytes/sec }{ }^{a}\end{array}$} & \multicolumn{6}{|c|}{ Human output data channels ${ }^{a}$} & \multirow{3}{*}{$\begin{array}{l}\text { Data received } 10,000 \text { faster } \\
\text { than the rate at which it can } \\
\text { be transmitted }\end{array}$} \\
\hline & & Touch & Signs & Writing & Sound & Speech & \\
\hline & & $<15 K$ & $<15 \mathrm{~K}$ & $<15 K$ & $<100 \mathrm{~K}$ & $<100 K$ & \\
\hline
\end{tabular}

${ }^{\mathrm{a}}$ Sources of channel capacity; Cochrane (1997, 2000; ${ }^{\mathrm{b}} \mathrm{K}=$ Kilobytes, M=Megabytes

Figure 1, Human constraints in transacting bytes

A methodology developed by Turnbull (2001b) described as "Transaction Byte Analysis" (TBA) provides a way to investigate, design, and compare organizations with either hierarchical or network architecture on a quantitative basis. TBA overcomes the problems identified Radner (1992: 1384) who stated: "I know no theoretical research to date that compares the relative efficiency of hierarchical and non-hierarchical organizations within a common model" and of Demb \& Neubauer (1992) who wanted a way to "compare systems of corporate governance within and between cultures”. More generally, Demsetz (1991: 159) states: "a more complete theory of the firm must give greater weight to information cost than is given either in Coase's theory or in theories based on shirking and opportunism which have not gone far enough". Jensen (1993: 873), an author of agency theory widely used in corporate governance analysis observed: "we're facing the problem of developing a viable theory of organizations". While the emergence of network firms led Zingales (2000) to state in regards to existing theories of the firm that: "they seem to be quite ineffective in helping us cope with the new type of firms that are emerging”. 
TBA subsumes Transaction Cost Economics (TCE) developed by Williamson (1975; 1985) when costs become a proxy for data and its higher order social constructs of information, knowledge, and wisdom. Information represents data that provide meaning to an observer. Meaning from non-mathematical languages cannot be quantified. Nor can knowledge that represents information that can be useful for analysis or action. Likewise wisdom cannot be quantified as it represents the knowledge of when to use knowledge. However, no change in the state of information, knowledge or wisdom can occur without the transaction of bytes.

The sharing of information is dependent on patterns of data being interpreted in a similar manner by senders and receivers. To interpret data in an identical way, the neurological circuits of individuals (or creatures) sending data needs to be closely aligned with neurological circuits of the individual receiving the data. However, the neurological architecture of even identical twins can vary according to how different external stimuli affect their brain development. "The number of neurons in the human brain is estimated at approximately 100 billion, with an average of 1,000 connections per neuron, for a total of 100 trillion connections” (Kurzweil 1999: 119). Such large numbers means that no two or more individuals can be expected to have identical neurological architecture for interpreting an identical meaning from a given pattern of data. However, cultural homogeneity with training and conditioning can commonly achieve useful approximations of shared meaning.

Notwithstanding these observations, the word "information" is commonly used ambiguously to mean either meaningful data or just data. This ambiguity will be accepted as it is in everyday usage to allow quotations that use the word "information" to be accepted without qualification. Examples are Williamson (1985: 283) cited above and for Kurzwiel (1999: 120) where he states: "The brain relies on a large degree of redundancy and a relative low density of information storage to gain reliability and to continue functioning effectively despite a high rate of neuron loss as we age”.

\subsection{Architecture of nature}

The transaction of bytes involves perturbations in matter and/or energy. Minimizing the transaction of bytes is required to minimize the energy and/or matter creatures require to receive, store and process data required to sustain their existence as well as to avoid exceeding their physiological and neurological limits in transacting bytes. Minimizing the transaction of bytes in firms would minimize costs to allow TBA to subsume TCE. 
Over billions of years creatures have evolved sustainable systems of self-regulation and governance based on survival of the fittest. Survival provides a basic criterion for achieving self-regulation and self-governance. However, competition for survival means that this needs to be achieved in the most economic, efficient and resilient manner. This in turn requires the most efficient and reliable system for obtaining signals from the environment, comparing them with past signals, processing the data and activating responses to allow creatures to sustain their existence from unknowable complex threats and opportunities.

Nature creates complexity and controls complexity by decomposing it into what Simon (1962) described as "sub-assemblies" (1962: 472) or "stable intermediate forms" (1962: 473) to create "nearly decomposable systems, in which the interactions among the sub-systems are weak, but not negligible" (1962: 474). These "sub-assembles", "forms" and "sub-systems" were described by (Koestler 1967) as "holons". Koestler describes a hierarchy of holons as a "holarchy" to distinguish it from a hierarchy where there is a direct "boss" (Simon 1962: 468) in a command and control system. Other terms are used to describe holons like "modules" or "capsules" (Baldwin \& Clark 2006), "viable systems" (Beer 1985), "chaords" (Hock 1999), "wholes", "systems", "org", "entities" or "cooperative heterarchy" noted by Mathews (1996).

An inherent characteristic of holons is that they contain contrary characteristics such as centralization/decentralization of control, bottom-up/top-down processes, autonomous/integrated behavior and order/ambiguity (Mathews 1996: 52-53). The ability of organizations to possess contrary characteristics was noted by Dee Hock the founding CEO of the credit card company VISA international. To describe the organization he designed with these characteristics he coined the word "chaord" by combining the contrary words "chaos" and "order" (Hock 1999). The combination of contrary characteristics in physical structures allows new properties to emerge with tensional integrity or what Buckminster Fuller (1961) described as "tensegrity".

Fuller created geodesic domes by combing contrary materials like wire that has strength in tension and struts that have strength in compression. The combination of these contrary materials allows the greatest area to be covered by a structure with the least weight. The rich variety of stable or dynamic configurations that a human body can obtain arise from combining bones that work best in compression with muscles that work best in tension. Tensegrity is a fundamental feature of the "architecture of life" as described by Ingber (1998) who reports that human cells are constructed from material with contrary properties. The reason is because like geodesic domes it provides "a maximum amount strength for a given amount of building material" (Ingber 1998: 32). Tensegrity PAGE 7| Journal of Corporate Governance, Insurance, and Risk Management | 2017, VOL. 4, Series. 2 
has been adopted by evolution as the most efficient and resilient way to create and sustain living things.

DNA programs social creatures, including humans, to possess contrary characteristics like being competitive/cooperative, suspicious/trusting, selfish/altruistic and so on. I described this behavior as "Social Tensegrity" (Turnbull 2001b: 84). Social tensegrity introduces organizational integrity without the need for individual integrity advocated by Jensen (2009). TBA reveals the competitive advantages of social tensegrity. It provides creatures with a requisite variety of responses to discover those responses that will sustain their life in complex unknowable dynamic environments. Social tensegrity provides "a requisite number of responses to manage uncertainty while using minimum energy and/or materials to transact bytes (Turnbull 2001b: 134).

To paraphrase Ingber (1998: 32), it appears that organizations with holonic architecture are able to provide "a maximum amount of control (strength) for a given amount of bytes (building material)". In other words social tensegrity in organizations maximizes their ability to self-control/selfregulate/self-govern with the minimum transaction of bytes. This in turns explains how network governance can provide competitive advantages and resiliency compared with hierarchies that create information overload, and lack a requisite variety of communication and control channels to control/regulate complexity. The operating and/or competitive advantage of network organizations increases as activities increase in complexity (Craven, Piercy \& Shipp, 1996; Jones, Hesterly \& Borgatti, 1997).

Hierarchies depend upon obedience and conformity. In this way hierarchies inhibit the ability of individuals to act in a contrary manner as encouraged by their DNA. This problem was identified by Hock (1995: 4) in the last century who stated that:

Industrial Age, hierarchical command and control pyramids of power, whether political, social, educational or commercial, were aberrations of the Industrial Age, antithetical to the human spirit, destructive of the biosphere and structurally contrary to the whole history and methods of biological evolution. They were not only archaic and increasingly irrelevant; there were a public menace.

Hock (1999: 6) observed before the financial crises over the last decade that:

We are experiencing a global epidemic of institutional failure that knows no bounds. We must seriously question the concepts underlying the current structures of organization 
and whether they are suitable to the management of accelerating societal and environmental problems - and, even beyond that, we must seriously consider whether they are the primary source of those problems.

The institutional problem of individuals being inhibited to be contrary is that there is little inbuilt ability for hierarchical organizations to generate sufficient variety of responses to manage complexity. This problem is overcome with holonic organizations that possess contrary behavior. The importance of being able to generate a rich variety of responses to manage complexity arises from the cybernetic law of requisite variety that states: "only variety can destroy variety" (Asbhy 1956: 207). In regards to the law of requisite variety Ashby (1956: 245) explained that: "Its importance is that if $\mathrm{R}$ [egulator] is fixed in its channel capacity, the law places an absolute limit to the amount of regulation (or control) that can be achieved by $\mathrm{R}$ [egulator], no matter how R[egulator] is re-arrange internally, or how great the opportunity in T [system]."

The variety of responses from any regulator/controller must be sufficient to handle the complexity of the variables involved. This is why complex firms cannot be reliably centrally controlled because they lack a requisite variety of independently acting controllers. Likewise, it becomes impossible for government regulators to reliably control complex firms on a centralized top-down basis.

The purpose of government regulators is to protect and further the interests of stakeholders and society who can be harmed by a firm or put at risk by a firm. To achieve their objective regulators require a requisite variety of controllers. It is the stakeholders who regulators have been created to protect that can provide the requisite variety of control. This is why stakeholder engagement becomes an essential requirement for either firms or their regulators to reliably control complex activities as illustrated in Section 4. It is stakeholders who can expeditiously and sensitively provide the bottom-up feedback correction to protect and further their interests and that of society.

These insights explain why so called governance best practices and government regulators cannot reliably protect stakeholders. Efficient, economic and effective control and regulation of complex firms requires stakeholders to be constructively engaged in the governance architecture. This explains the necessity for introducing network governance and network regulation when complex firms are involved. The engagement of stakeholders into the governance and regulatory architecture provide a basis to further the self-regulation and self-governance of firms. The conditions for achieving self-control/regulation/governance are set out in Turnbull (2001b: 118). 
Adoption of network governance would change the role of government. It would reduce: (a) the need for regulators; (b) the size and costs of government while (c) enriching democracy at the grass roots level to sustain society and the environment. The role of government would become indirect, a condition required by the law of requisite variety to amplify regulation by supplementation (Ashby 1956: 270). In the words of US Vice President Al Gore the role of government would be "to imprint the DNA" (Gore 1996) of institutions so they could become self-governing.

DNA in social creatures only survives if it programs its host to possess contrary behavior with manifold ying/yang characteristics such as approach/avoidance, etc. Contrary behavior introduces a "requisite variety" (Ashby 1956: 206) of responses that introduces checks and balances to permit the selection of the most appropriate reactions in uncertain, dynamic complex life threatening environments. While small-brained insects can survive in such environments, the 2008 financial crisis revealed that large brained highly intelligent so-called "masters of the universe" could not. The problem is that most large corporations are governed through top down command and control hierarchies that resists contrary views, bottom up initiatives or checks and balances. The inherent problems of centralized top-down governance are next considered.

\section{FAILURE OF TOP-DOWN ONLY GOVERNANCE}

The failure of current laws, regulations and regulators to protect stakeholders arises because each relies on a top down approach. The evidence of nature and so the science of governance reveals that a bottom up approach is also essential to reliably regulate complex organizations operating in unknowable, dynamic environments. Lawmakers and their regulators cannot control firms if firm directors and/or executives in turn rely only on a top down control system without independent feedback signals from everywhere else.

Network governance introduces bottom up control and communications from the very people governments and regulators are trying to protect. As illustrated by the John Lewis Partnership, the Mondragón Corporacion Cooperativa (MCC) and by Figure 4, it is plain common sense for stakeholders to be included in the governance architecture of firms. Michael Porter (1992) recommended this approach in his report to the US government on competiveness. But his ideas were not adopted because stakeholders on a US unitary board would introduce conflicts of interest.

What Porter did not take into account is that bottom up feedback communication in Japanese and German firms are channeled through a different board. Such boards not only obtain, (i) the information to act but also; (ii) the incentive; (iii) power and (iv), capability to act. These four PAGE 10| Journal of Corporate Governance, Insurance, and Risk Management | 2017, VOL. 4, Series. 2 
conditions are not typically present in US/UK type of disconnected capitalism as shown by Turnbull \& Pirson (2012). It is by making such connections that network governance can reduce risks and provide competitive advantages.

Network governance also separates conflicts of interest and introduces different viewpoints to create checks and balances to establish more mutually effective and resilient operations. In addition, by separating the governance and management powers of directors, governance and management functions can then paradoxically be integrated throughout the firm. How this is achieved in practice by the Mondragón stakeholder controlled cooperatives is illustrated in Figure 7.3 in Turnbull (2001b: 245). Kay (1996) and Givens (1991) describe how stakeholder engagements can be added to traditional hierarchical firms.

The integration of management and governance in turn introduces self-regulation and selfgovernance as found in nature. Network governance provides a way to overcome the built in problems with current ideas of "best" practices for a unitary board to provide systemic solutions as indicated in Table 1. Details of "The corrupting powers of a unitary board" are presented in Turnbull (2001b: 115).

Network governance empowers Governors who take of the roles of NEDs, with information independently of management to monitor management. Without network governance, common sense suggests that the more a director is considered to be independent then the more the director lacks authority and knowledge to monitor and evaluate management and the business operations. This explains why there is no compelling empirical evidence that NEDs can improve performance or prevent disasters. On the contrary, Bhaghat \& Black (2002) found evidence that increasing the number of NEDs on a board reduces performance.

The proliferation of governance codes arise because corporate lobbyists argue that to remain competitive firms need governments to adopt a "light touch" to allow self-regulation. But belief in self-regulation is irresponsible and dangerous with firms governed by a unitary board that allows directors absolute power to identify and manage their conflicts of interest (Jackson 2007). Selfregulation only becomes possible firstly if a division of powers is created and secondly if stakeholders become empowered to assists in protecting themselves. As noted above stakeholder engagement also provides a way to increase competitiveness. So self-regulation and competitiveness can be achieved together. In addition network governance provides a way to make firms directly accountable to stakeholders for their social and environmental concerns.

PAGE 11| Journal of Corporate Governance, Insurance, and Risk Management | 2017, VOL. 4, Series. 2 
Table 1 How ecological governance overcomes problems of a unitary board

\begin{tabular}{|c|c|c|}
\hline \multicolumn{2}{|c|}{$\begin{array}{l}\text { Systemic problems for unitary board } \\
\text { Non-Executive Directors (NEDs): }\end{array}$} & $\begin{array}{l}\text { Systemic solutions from introducing network governance used } \\
\text { by nature described as "ecological governance": }\end{array}$ \\
\hline 1 & $\begin{array}{l}\text { Suspicion by outsiders that the } \\
\text { absolute power of directors to } \\
\text { identify and manage their own } \\
\text { conflicts of interest might corrupt } \\
\text { the directors and/or the business. }\end{array}$ & $\begin{array}{l}\text { Corporate charter establishes a governance board and a } \\
\text { management board of directors elected by cumulative voting } \\
\text { with one vote per share and Governors with one vote per } \\
\text { shareholder. Governors control auditors, director nomination } \\
\text { and pay with veto powers when conflicts exist for directors } \\
\text { (Dallas 1977). }\end{array}$ \\
\hline 2 & $\begin{array}{l}\text { No creditable systematic process } \\
\text { for NEDs to determine when their } \\
\text { trust in management might be } \\
\text { misplaced. }\end{array}$ & $\begin{array}{l}\text { Corporate charters makes provision for any class of stakeholders } \\
\text { to elect a representative board to meet with governors } \\
\text { independently of management or directors to provide feedback } \\
\text { and/or feed forward competitive intelligence to them and/or } \\
\text { mgrs. }\end{array}$ \\
\hline 3 & $\begin{array}{l}\text { Exposure of NEDs to personal } \\
\text { liabilities and loss of reputation } \\
\text { from management misdeeds. }\end{array}$ & $\begin{array}{l}\text { Misdeeds of executives are the responsibility of the directors' as } \\
\text { Governors do not have power to manage business operations. As } \\
\text { indicated in Figures } 3 \& 4 \text { directors could include non-executives. }\end{array}$ \\
\hline 4 & $\begin{array}{l}\text { No systemic access for NEDs to } \\
\text { information opposing } \\
\text { management views and so for } \\
\text { evaluating management } \\
\text { independently of managers. }\end{array}$ & $\begin{array}{l}\text { Feedback from establishment of one or more "Employee } \\
\text { Assemblies", "Creditors Councils" and "Debtors Forums" who } \\
\text { may appoint a "Stakeholder Congress" to advise on KPIs used to } \\
\text { determine executive appointments and their remuneration. }\end{array}$ \\
\hline 5 & $\begin{array}{l}\text { No diversity of information } \\
\text { sources to cross check integrity of } \\
\text { management information or } \\
\text { obtain second or more opinions. }\end{array}$ & $\begin{array}{l}\text { Diversified feedback provided from specialized stakeholders } \\
\text { groups and their Boards with informal access to Government } \\
\text { regulator who chairs their Stakeholder Congress. Congress chairs } \\
\text { AGM determining pay and election of Directors and Governors. }\end{array}$ \\
\hline 6 & $\begin{array}{l}\text { Coping with data and information } \\
\text { overload. }\end{array}$ & $\begin{array}{l}\text { Compliance information and liabilities transferred to directors } \\
\text { with option of strategic analysis transferred to a supervisory } \\
\text { board as found in Europe. }\end{array}$ \\
\hline 7 & $\begin{array}{l}\text { Difficulties in detecting biases, } \\
\text { errors and omissions in reports } \\
\text { from managers. }\end{array}$ & $\begin{array}{l}\text { Access to a requisite variety of independent crosschecking } \\
\text { sources of stakeholder feedback to obtain accuracy as much as } \\
\text { desired as demonstrated by Shannon (1948). }\end{array}$ \\
\hline 8 & $\begin{array}{l}\text { Inadequate knowledge for } \\
\text { complex decision-making. }\end{array}$ & $\begin{array}{l}\text { Simplification of decision making by decentralization into to a } \\
\text { requisite variety of centers as described by Von Neumann } \\
(1947) \text {. }\end{array}$ \\
\hline 9 & $\begin{array}{l}\text { Board decision-making subject } \\
\text { biases in its membership - }\end{array}$ & $\begin{array}{l}\text { Exposed to multiple diverse and contrary viewpoints raised by } \\
\text { stakeholders to force consideration of taboo topics and avoid }\end{array}$ \\
\hline
\end{tabular}

PAGE 12| Journal of Corporate Governance, Insurance, and Risk Management | 2017, VOL. 4, Series. 2 


\begin{tabular}{|l|l|l|}
\hline 10 & Gender biases, etc. & culture of don't ask don't tell. \\
& Lack of will to act against & $\begin{array}{l}\text { Governors not captive to management information and/or } \\
\text { executive powers and influence with independent power and/or } \\
\text { influence on director nomination, pay and tenure. }\end{array}$ \\
\hline 11 & $\begin{array}{l}\text { Lack of a systemic way to safely } \\
\text { blow the whistle on errors, } \\
\text { misdeeds, etc. }\end{array}$ & $\begin{array}{l}\text { Provided privately by network of boards connected to the } \\
\text { government regulator and/or firm specific employee } \\
\text { ombudsperson. }\end{array}$ \\
\hline 12 & $\begin{array}{l}\text { Impossibility of directly } \\
\text { controlling/countering complex } \\
\text { variables/risks. }\end{array}$ & $\begin{array}{l}\text { Control amplified indirectly through requisite variety of } \\
\text { stakeholders acting as co-regulators (Ashby 1956: 265). }\end{array}$ \\
\hline
\end{tabular}

The fact that direct amplification of reliable control or regulation is impossible has profound and widespread implications for the structure of complex organizations in the public, private and/or nonprofit sectors. It means that all complex organizations need to include stakeholders as co-regulators to supplement the variety of control to improve their regulation. It also reveals the futility of top down proposals to improve corporate governance and business regulation. Some legal scholars have recognized the need for a division of board powers (Braithwaite 1997, Dallas 1997) and the need for "networked regulation" (Tomasic \& Akinbami 2011) as is next considered.

\section{NETWORK GOVERNANCE}

Network governance can be introduced by changing corporate constitutions (Turnbull 2000a). A basic requirement is the introduction of a division of powers. This allows checks and balances to exist as found in nature, our bodies and in our brains. My PhD research revealed how the architecture of the MCC and the constitutions of its member firms exemplify "the architecture of life" (Ingber 1998). An architecture that is ubiquitous throughout the universe (Turnbull 2001b: 130, 221).

However, before reaching my $\mathrm{PhD}$ research epiphany, it seemed like just plain common sense to introduce elements of network governance into the constitutions of start-up-firms that I founded. I had two motives: (1) to raise millions of dollars at the lowest cost, and (2) protect my reputation as a serial entrepreneur in the event the business did not exceed. Both objectives were achieved (Turnbull 2000a, 2002c).

I introduced three basic changes. First, removing the absolute power of directors to identify and manage their own conflicts of interests to avoid the possibility of corrupting themselves and/or the business. Second, removing unethical conflicts of interest that arise for: (a) directors when they 
appoint and pay the auditor who judges them, and (b) auditors when they are selected and paid by the directors whose accounts they judge as shown in Figure 2.

Fig. 2 Unethical conflicts of unitary board

In a law court it is unethical for a Judge to be paid and controlled by those being judged.

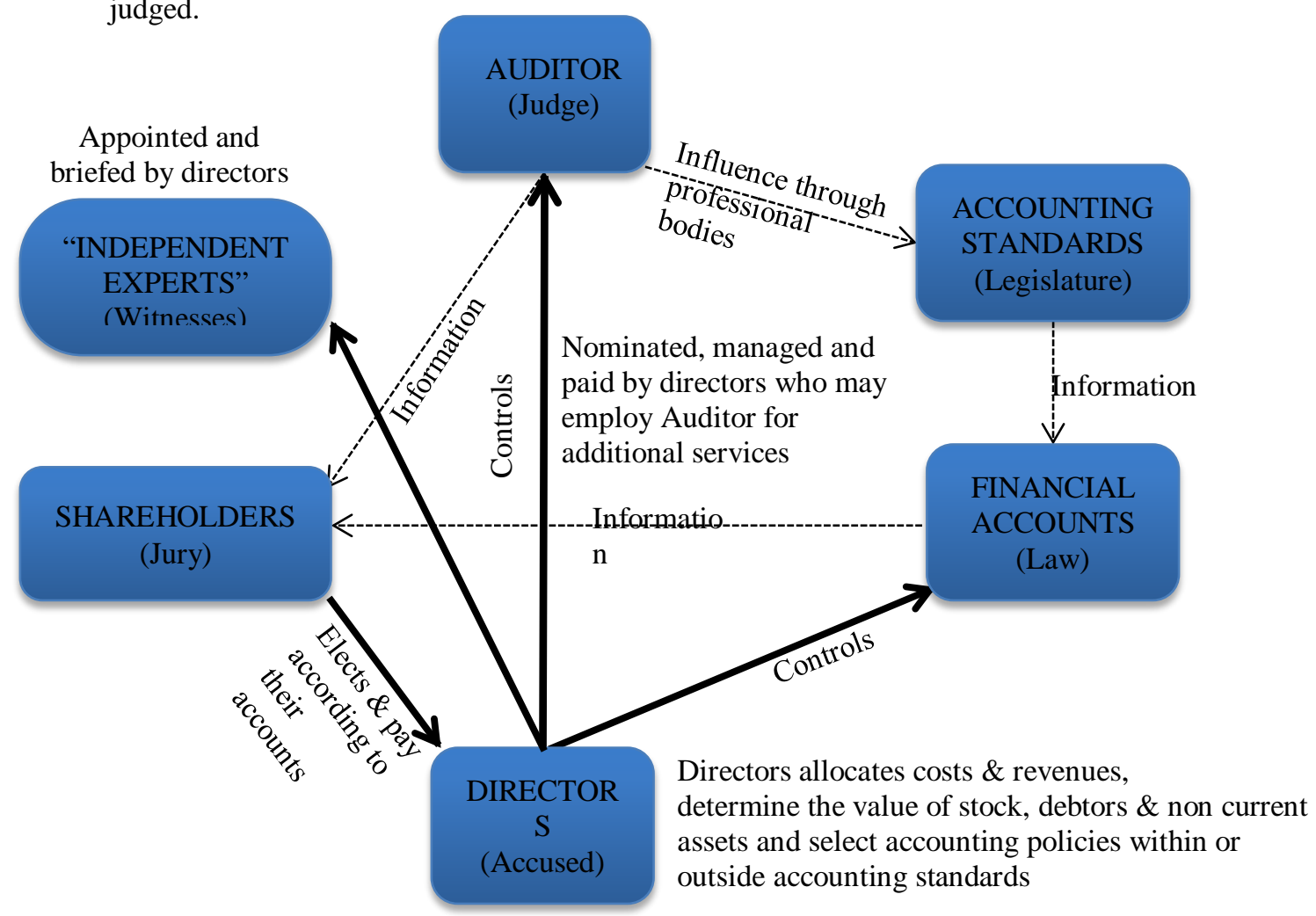

Judges in a law court cannot claim to be independent when they are selected and paid by the people they are judging. If the judge then attested that he/she was "independent", as auditors do, then it would be the judge that would be sent to jail. The third change was to remove the power of any director to chair a meeting of shareholders where shareholders were holding directors to account, determining their pay and/or their appointment. Instead, the chairman of a shareholders' audit committee described as a "Governance Board" chaired the AGM. Refer to Figure 3.

The separation of powers that I introduced were similar to those typically introduced by venture capitalists and bankers for providing finance. These first steps in introducing network governance do not represent a radical precedent nor would they inhibit the ability of businesses to add value and grow. Network governance protects the reputations of directors by removing suspicion and questions from stakeholders and the media that directors could be feathering their own nests rather than creating nest eggs for others. Refer to row 1 , Table 1 
Fig. 3 Network governance - separation of powers is the the first step to be ethical and competitive

(As commonly found in shareholder agreements with venture capitalists)

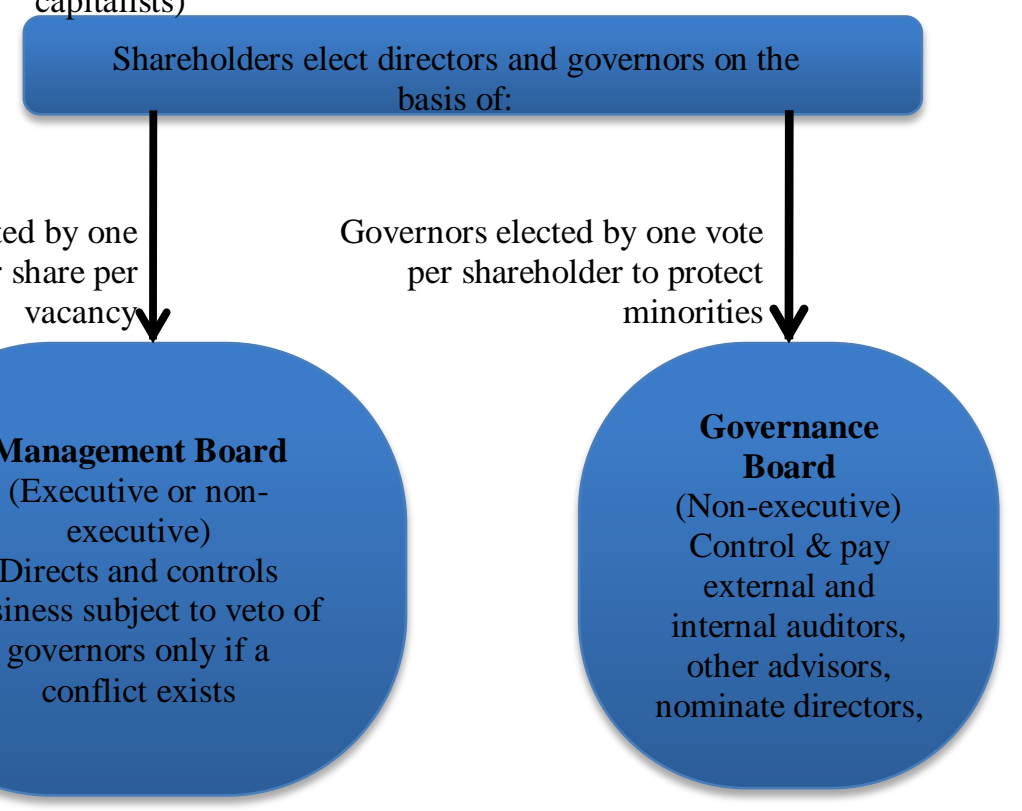

Fig. 4 Network governance - bottom up added to top down

Non-executive directors and governor not conflicted and obtain intelligence independently of managers to direct and control operations.



PAGE 15| Journal of Corporate Governance, Insurance, and Risk Management | 2017, VOL. 4, Series. 2 


\section{UNDERSTANDING THE ADVANTAGES OF NETWORK GOVERNANCE}

Company directors, scholars and governance experts typically reject the idea of network governance when they note the complexity of networked governed firms such as presented in Turnbull (2001b: 207). While it may be counter intuitive, the tasks of individuals can be simplified by greater organization complexity as illustrated by the MCC (Turnbull 2001b: 245). Simplification in hierarchies is achieved through limiting the span of control and by introducing multidivisional forms of organizations (Williamson 1975: 32).

The eye glazing, mind-numbing complexity of the MCC control and communication architecture presented in Turnbull (2001b: 207) represents what is described as "state description" (Simon, 1962; 479; De Vany, 1998). Like the complexity of nature it can be explicated simply from a "process description" that describes how complexity is constructed from simpler components as presented in Turnbull (2001b: 221) ${ }^{1}$. As noted by Simon (1962: 479) "The problem of finding relatively simple descriptions for complex systems is of interest not only for an understanding of human knowledge of the world but also for an explanation of how a complex system can reproduce itself."

Centralized governance through hierarchies are now well past their "use by date" for large complex financial institutions. Pirson \& Turnbull (2011) explain how firms judged too big to fail are likely also to be too big to be reliably managed, governed or regulated without network governance. In our follow up article we raise the question "Could the 2008 US financial crisis have been avoided with network governance?" (Turnbull \& Pirson, 2012).

Some of the benefits of network governance for NEDs who become "Governors" are next considered. The advantages for auditors, managers, investors, stakeholder and regulators are also outlined in the following subsections.

\subsection{Governors}

Nine of the benefits for NEDs being elected separately by shareholders to become Governors are outlined below:

1) Role simplified and information overload reduced by the decomposition of decision-making labor that also minimizes compliance responsibilities and so personal liabilities (Clarke 2006; Page 2009; Rodriques 2007; Turnbull 2001b: 245).

\footnotetext{
${ }^{1}$ The complexity of the MCC is parsimoniously summed up in the four columns and five rows of "Table 6.1, Holon typology of Mondragón" on page 221 of Turnbull (2001b). Table 6.1 allow the complexity of the MCC to be revealed as a consistent continuum of how the complexity of life is created and the universe emerges as shown in "Table 3.8, Holarchy: Hierarchy of Holons" on page 130. Table 6.1 also illustrates the point made by Simon (1962: 479): "the task of science is to make use of the world's redundancy to describe that world simply."
}

PAGE 16| Journal of Corporate Governance, Insurance, and Risk Management | 2017, VOL. 4, Series. 2 
2) Monitoring and supervisory roles legitimatized by obtaining access rich variety information to evaluate management and the business independently of management (Shannon 1948).

3) Ability to cross check management reports for errors, biases, distortions, omissions and "spin" from additional independent communication channels from a diversity of stakeholders (Shannon 1948, Turnbull 2001b: 99).

4) Formal and informal access to industry, product and competitive intelligence and/or whistle blowers from systematized stakeholder engagement (Porter 1992; Turnbull 1997; 2000b, 2001a).

5) Creditable processes established on an independent systemic basis for learning when trust in management might be misplaced (Page 2009).

6) Exposure to most financial liabilities transferred to full time executives as NED not responsible for management decisions.

7) Unethical conflicts with financial auditor eliminated with exclusive control of internal auditor (Turnbull 2002c, 2008a, 2009).

8) Residual personal conflicts on NEDs own pay and tenure taken over or mediated by stakeholder congress.

9) Intelligence on Key Performance Indicators (KPIs) for executives provided by stakeholders exposed to services, costs and/or risks from management (Turnbull, 2002b, 2009).

10)

\subsection{Auditors}

External auditors obtain substantial benefits from enhancing their integrity, professionalism and role in four ways.

1) Unethical conflicts removed by Auditor no longer selected, appointed and remunerated directors whose accounts they are judging (Gitins 2002; Hatherly 1995; Haywood 2003; O'Connor 2004; Shapiro, 2004; Turnbull 2008a).

2) Unconscious bias in judging accounts is removed as identified by Bazerman, Loewenstein \& Moore (2002).

3) The possibility of the auditor not being seen as being independent of the officers whose accounts they are judging is removed to remove the need for audit partner or audit firm rotation (Bazerman, Morgan \& Lowenstein1997, Shapiro 2004, and Haywood 2003).

4) Access is obtained to a rich variety of alternative communication channels to cross check the integrity of corporate data independently of management (Shannon 1948).

5)

\subsection{Management}

PAGE 17| Journal of Corporate Governance, Insurance, and Risk Management | 2017, VOL. 4, Series. 2 
Management obtains formal systemic processes for accessing stakeholder resources for enhancing operations.

1) Formal relationships established to facilitate and/or arbitrate Total Quality Management (TQM) and Just in time (JIT) processes with relevant stakeholders (Turnbull 1997; 2000a,b; 2001a).

2) Process for accessing innovational, operational and competitive intelligence from stakeholders that might not otherwise be provided on a systematic basis (Hippel 1986).

3) Facilitate stakeholder loyalty and engagement to constructively support the firm (Givens 1991).

4) Systematic process to quickly learn about problems and take corrective actions before governors/regulators.

5) Harness pro-bono stakeholder resources for continuous improvements (Givens 1991; Turnbull 1997; 2000a,b; 2001a).

6) Compliance processes integrated into management.

7)

\subsection{Stakeholders}

Those parties who are affected by the firm and described as stakeholders obtain formal direct and contingently influential relationships to protect and further their interests as outlined below and discussed in greater details by Givens (1991), Kay (1996), and Turnbull (1997, 2000a,b, 2001a).

1) Formal access to contribute continuous improvement programs for mutual benefits.

2) Direct access to correct poor quality goods/services and relationships.

3) Direct, quicker and more responsive access to protect and further their own interest than regulators, courts and/or public protests.

4) Strengthen constructive working relationships and mediate others.

5)

\subsection{Regulators}

The role of regulators is enhanced while their size and cost can be reduced in four ways as outlined below:

1) Amplification of regulation through stakeholder supplementation as co-regulators (Ashby 1956: 265);

2) Higher integrity of monitoring communications through multiple stakeholder feedback (Shannon 1948);

3) Improved formal and informal access to monitor firms and the integrity of the self-regulating processes of firms (Turnbull 2001b: 118);

4) Role changes to promoting and supervising the integrity of firm self-governance (Gore 1996). PAGE 18| Journal of Corporate Governance, Insurance, and Risk Management | 2017, VOL. 4, Series. 2 


\section{CLOSING REMARKS}

Even without applying the insights of cybernetics this paper reveals that the current dominant form of US/UK governance architecture and practices are not supported by common sense, ethics, theory or compelling empirical evidence. The new types of nonhierarchical firms that concerned Zingales (2000) include those with network governance. These diminish the relevancy of agency theory (Jensen \& Meckling 1976) and stewardship theory (Davis, Schoorman and Donaldson 1997) commonly used by governance scholars. The diminishing arises because the role of agents and stewards can become irrelevant and/or interchanged in a network at different times.

The impotency and/or irrelevancy of governance laws, regulations, regulators and codes is demonstrated by the many recent high profile and unexpected failures. For example there are manifold and continually changing definitions of director "independence" and confusion over the purpose of seeking independence (Clarke 2006; Page 2009). Rodrigues (2007) has noted the "fetishization of Independence" not withstanding that extensive empirical survey by Bhagat \& Black (2002) that found no correlation of director independence and performance with US boards. The evidence suggested that firm performance decreases as the independent directors on a board are increased. This supports the common sense observation considered earlier.

Likewise there has been a long historical confusion over the different legal purposes of external auditing in the UK and the US that has led to confusion about the role and structure of audit of committees (Turnbull 2008a). There is denial by practitioners in recognizing the unethical relationship between auditors and directors as raised by a number of scholars such as: Bazerman, Morgan \& Lowenstein (1997); Bazerman, Loewenstein \& Moore (2002); Haywood (2003); O'Connor (2004); Shapiro (2004); Romano (2004). Hatherly (1995) proposed that a shareholder committee should control the auditor as indicated in Figures 3 and 4 as is the practice in some European countries like France (Analytica 1992: 107), Hungary (Lempert 2003), Italy (Melis 2004) and Russia (Gitins 2002).

Regulators seem to be captive to practitioners and so limit their consideration of changes to mainly those that are only cosmetic in nature. They then falsely claim that such changes increase audit independence when the inherent unethical conflicts of interest still remain. Changes like limiting non-audit services, rotating partners and/or rotating auditors do not remove the unethical relationships. The ability of auditors to legally attest that they are "independent" illustrates how this word has become perverted from its widely accepted meaning. It is not a good look for directors and auditors to be seen by the public as not being able to recognize unethical and/or untrue relationship PAGE 19| Journal of Corporate Governance, Insurance, and Risk Management | 2017, VOL. 4, Series. 2 
by stating that in some obscure technical and largely irrelevant basis they can classify themselves as being "independent".

Likewise, fundamental changes in the concentration of corporate power and influence are little considered in new reforms (Sharpe 2010). It is time to fundamentally rethink the roles of directors, governance and regulators. The very fact that codes of behavior are required proves the inadequacy and/or irrelevancy of corporate laws, regulations and regulators. In the natural world, the control and communication system in creatures is programmed to sustain their existence on a resilient selfregulating basis without codes. Unless there is fundamental rethinking the endless revisions of laws, regulations and codes will continue to meet the political and social imperatives of being seen to being doing something to reduce unexpected failures. Governance science reveals that fundamental change is required to adopt the control and communication architecture found in nature.

Re-designing the architecture of corporate governance could be introduced on an incremental basis. In Australia I negotiated with the regulator to avoid the cost of calling an AGM to change the auditor. The exemption was granted because the regulator accepted that the democratically elected shareholder audit committee protected minority shareholders better than shareholders voting on the usual plutocratic basis of one vote per shareholder. By such processes corporations could negotiate incremental de-regulation. The UK Financial Reporting Council supported this approach by sponsoring the presentation of my paper on the 'The Theory and Practice of Government Deregulation' to a conference ${ }^{2}$ for regulators (Turnbull 2008c).

As documented in this paper there is growing concern by legal and other scholars over the role of directors, governance and regulation in English speaking countries (Howson 2009, Sharpe 2010, Sun, Steward \& Pollard 2011, Vasudev \& Watson 2012). These and other scholars provide evidence of various so-called "best practices" being unethical, conflicted, counterproductive, naïve and dangerous for directors, shareholders and regulators.

There is also growing acceptance by other leading scholars of the contrary views outlined in this paper. These include my PhD examiners, editors who have solicited my contrary views in their reference books and textbooks and the many referees involved in publishing Turnbull (1995; $2000 a, b ; 2002 a, b ; 2008 a, b, c ; 2009 ; 2010 ; 2011 ; 2012)$. These writings provide additional details of the science and practices self-regulation and self-governance.

$22^{\text {nd }}$ Cambridge University Conference on 'Regulation, Inspection \& Improvement, Judge Business School Centre for Business Research, 12 September 2007.

PAGE 20| Journal of Corporate Governance, Insurance, and Risk Management | 2017, VOL. 4, Series. 2 
The contribution of this paper is to present both a practical and a theoretical overview for rethinking director's roles, governance and regulation. The theoretical framework provided by governance science identifies the impossibility of direct reliable control, regulation and/or governance of large complex firms with a unitary control structure by the firm or its regulator. This means that regulators are being irresponsible to allow large complex firms to exist without network governance (Jackson 2007; Pirson \& Turnbull 2011; Turnbull \& Pirson 2012).

As shown in section five, network governance provides numerous practical advantages for directors, auditors, management, stakeholders and regulators. The conclusion that network governance should be required for large complex firms is supported by both practical and theoretical considerations. The constructive engagement of stakeholders through network governance introduces direct democratic process for improving the social and environmental behavior of firms in way to reduce the size, intrusiveness and cost of government. It is in these ways and for these reasons that a sustainable future can be established for corporate governance practices grounded in the science of governance.

\section{REFERENCES}

Analytica (1992). Board directors and corporate Governance: Trends in the G7 countries over the next ten years. Oxford, England: Oxford Analytica Ltd.

Ashby, W.R. (1956). An introduction to cybernetics. London: Chapman \& Hall Limited.

Baldwin, C.Y. \& Clark, K.B. (2006). Where do transactions come from? A nework design perspective on the theory of the firm. Harvard NOM Working Paper No. 06-12.

Bazerman, M.H., Loewenstein, G. \& Moore, D.A. (2002). Why good accountants do bad audits? Harvard Business Review, 80(11), 95-98.

Bazerman, M.H., Morgan K.P. \& Loewenstein G.F. (1997). The impossibility of auditor independence. Sloan Management Review, 38(4), 89-94.

Beer, S. (1985). Diagnosing the system for Organization. New York: John Wiley.

Bhagat S. \& Black B.S. (2002). The non-correlation between board independence and long-term firm performance. Journal of Corporation Law 27(2), 231-273.

PAGE 21| Journal of Corporate Governance, Insurance, and Risk Management | 2017, VOL. 4, Series. 2 
Braithwaite, J. (1997). On Speaking Softly and Carrying Big Sticks: Neglected Dimensions of a Republication Separation of Powers. University of Toronto Law Journal, 47, 305-361.

Clarke, D.C. (2006). Setting the Record Straight: Three Concepts of the Independent Director. GWU Legal Studies Research Paper No. 199, George Washington University Law School.

Cochrane, P (2000). Hard drive: Bandwidth and brandwidth. 6 April, London: Telegraph.

Cochrane, P. (1997). Private e-mail communication to the author dated December 21 when Head of British Telecom Research Laboratories, UK.

Craven D.W., Piercy N.F. \& Shipp S.H. (1996). New organizational forms for competing in highly dynamic environments: The network paradigm. British Journal of Management 7(3), 203-218.

Dallas, L.L. (1997). Proposals for reform of corporate boards of directors: The dual board and ombudsperson. Washington and Lee Law Review, 54(3), 92-146.

Davis J.H., Schoorman F.D. \& Donaldson L. (1997). Towards a stewardship theory of management. Academy of Management Review, 22(1), 20-47.

De Vany, A. (1998). How much information is there in an economic organization and why can't large ones be optimal? Brazilian Electronic Journal of Economics, 1(1) July.

Demb, A. \& Neubauer, F.F. (1992). The corporate board: Confronting the paradoxes. Oxford: Oxford University Press.

Demsetz, H. (1991). The theory of the firm revisited. The nature of the firm: Origins, evolution and development, eds, O.E. Williamson, \& S.G. Winter, (pp. 159-178), New York: Oxford University Press.

Dunbar, R.I.M. (1993). Co-evolution of neocortical size, group size and language in humans. Behaviorial and Brain Science, 16, 681-735.

Fuller, B.R. (1961). Tensegrity. Portfolio and Art News Annual, No. 4. 
Gitins, M.M. (2002). Letter of 10 December to Securities and Exchange Commission, Washington D.C. Re: Conflict with Russian Law under Section 301 of the Sarbanes-Oxley Act of 2002.

Givens, B. (1991). Citizens' Utility Boards: Because utilities bear watching. San Diego, California: Centre for Public Interest Law, University of San Diego School of Law.

Gore, A. (1996). The Technology Challenge: What is the role of science in American society? Prepared remarks delivered to American Association for the Advancement of Science. 12 February. Baltimore, Washington, DC: Office of the Vice President.

Hatherly, D.J. (1995). The case for the shareholder panel. European Accounting Review, 4 (3), 535553.

Hayward J. (2003). Thinking not ticking: Bringing competition to the public interest audit. London: Centre for the Study of Financial Innovation (CSFI).

Hippel, E. von (1986). Lead Users: A Source of Novel Product Concepts. Management Science, 32(7), 791-805.

Hock, D.W. (1995). The Chaordic Organization: Out of control and into order. World Business Academy Perspective 9(1): 4.

Hock, D.W. (1999). Birth of the Chaordic Age. San Francisco, CA: Berrett-Koehler Publishers. Howson, N.C. (2009). When “Good” Corporate Governance makes "Bad” (Financial) Firms: The Global Crisis and the limits of private law. Mich. L. Rev, 108, First Impressions 44.

Ingber, D.E. (1998). The architecture of life. Scientific American, January: 30-39.

Jackson, R. (2007). Are Regulators and Stock Exchanges Irresponsible?’ Posted by Robert Jackson, Managing Editor, Harvard Law School Forum on Corporate Governance and Financial Regulation, Thursday 8 November 12:45 pm. Available at: http://blogs.law.harvard.edu/corpgov/2007/11/08/areregulators-and-stock-exchanges-irresponsible/.

Jensen M.C. (1993). The modern industrial revolution: Exit and the failure of control systems. Journal of Finance, 48(3), 831-880. 
Jensen M.C. \& Meckling W.H. (1976). Theory of the firm: managerial behavior: Agency costs and ownership structure. Journal of Financial Economics, 3, 305-360.

Jensen, M.C. (2009). Integrity: Without it Nothing Works. Rotman Magazine: The Magazine of the Rotman School of Management, 16-32.

Jones, C., Hesterly, W. S. \& Borgatti, S. P. (1997). A general theory of network governance: Exchange conditions and social mechanisms. Academy of Management Review, 22, 911-945. Kay, J. (1996). Regulating private utilities: The customer corporation. Journal of Co-operative Studies, 29:2, 28-46.

Koestler, A. (1967). The ghost in the machine. London: Hutchinson.

Kurzweil, R. (1999). The age of spiritual machines: When computers exceed human intelligence. New York: Viking.

Lempert, M. (2003). Corporate Governance at Matav. Paper presented to 6th International Conference on Corporate Governance and Board Leadership, Henley, 7 October.

Mathews, J. (1996). Holonic organizational architectures. Human Systems Management, 15, 27-54.

Melis, A. (2004). On the Role of the Board of Statutory Auditors in Italian Listed Companies. Corporate Governance: An International Review, 12(1), 74-384.

Neuman, von. J. (1947). Theory of games and economic behavior. New Haven, CT: Yale University Press.

O’Connor, S.M. (2004). Be careful what you wish for: How accountants and Congress created the problem of auditor independence. Boston College Law Review, 45(5), 741-828.

Page, A. (2009). Unconscious bias and the limits of director independence. University of Illinois Law Review, 2009(1), 237-294.

Pirson, M. \& Turnbull, S. (2011). Corporate Governance, Risk Management, and the Financial Crisis An Information Processing View. Corporate Governance: An International Review, 19(5): 459-470, September.

Porter, M. E. (1992). Capital choices: changing the way America invests in business. Boston, MA: Harvard Business School.

PAGE 24| Journal of Corporate Governance, Insurance, and Risk Management | 2017, VOL. 4, Series. 2 
Radner R (1992). Hierarchy: The economics of managing. Journal of Economic Literature 30(3), $1382-1415$.

Rodrigues, U. (2007). The Fetishization of Independence. The UGA Legal Studies Research Paper No. 07-007, University of Georgia Law School, March.

Romano, R. (2004). The Sarbanes-Oxley Act and the making of quack corporate governance. Yale ICF Working paper 04-37, ECGI, Finance. Available at: http://ssrn.com/abstract=596101.

Shannon, C. E (1948). The mathematical theory of communications. The Bell System Technical Journal, 27, 379-423 and 623-656.

Shapiro, A. (2004). Who pays the auditor calls the tune? Auditing regulation and client's incentives. Seton Hall Law Review, 30 June.

Sharpe, N.F. (2010). Rethinking board function in the wake of the 2008 financial crisis. Journal of Technology and Business Law, 5(1).

Simon, H. (1984). On the behavioral and rational foundations of economic dynamics. Journal of Economic behavior and Organization, 5 March 35-56.

Simon, H. (1962). The architecture of complexity. Proceedings of the American Philosophical Society, 106, 467-482.

Sun, W., Stewart, J. \& Pollard, D., eds, (2011). Corporate Governance and the Global Financial Crisis-International Perspectives, (pp. 50-74). Cambridge: Cambridge University Press.

Tomasic, R. \& Akinbami, F. (2011). Towards a New Corporate Governance after the Global Financial Crisis. International Company and Commercial Law Review, 8, 237-249.

Turnbull, S. (1995). Best Practice in the Governance of GBEs. In J. Guthrie (Ed.), The Australian Public Sector: Pathways to Change in the 1990s', (pp. 99-109). Sydney, Australia: IIR Pty. Limited.

Turnbull, S. (1997). Stakeholder Co-operation. Journal of Co-operative Studies, 3, 18-52, (no.88). 
Turnbull, S. (2000a). Corporate charters with competitive advantages. St. Johns Law Review, 74(44), 101-159.

Turnbull, S. (2000b). Stakeholder Governance: A cybernetic and property rights analysis. In R.I. Tricker (Ed.), Corporate Governance: The history of management thought, (pp. 401-413). London: Ashgate Publishing.

Turnbull, S. (2001a). The competitive advantage of stakeholder mutuals. In J. Birchall, (Ed.), The New Mutualism in Public Policy, Chapter 9, (pp.171-201). London: Routledge.

Turnbull, S. (2001b). The governance of firms controlled by more than one board: Theory development and examples. Sydney, Australia: Macquarie University $\mathrm{PhD}$ dissertation. Available at: http://ssrn.com/abstract=858244.

Turnbull, S. (2002a). A new way to govern: Organisations and society after Enron. London: The New Economics Foundation.

Turnbull, S. (2002b). The science of corporate governance. Corporate Governance: An International Review, 10, 256-272.

Turnbull, S. (2002c). Watchdog Boards: Past, Present and Future? Working Paper, February. Available at: http://papers.ssrn.com/abstract_id=608244.

Turnbull, S. (2008a). Muddled Auditing Practices. In C. Padmavathi \& A. Bellur, eds. Audit Committees: An Insight (pp. 36-46). Hyderabad, India: The ICFAI University Press.

Turnbull, S. (2008b). The science of governance: A blind spot of risk managers and corporate governance reform. Journal of Risk Management in Financial Institutions, 1(4), 360-368, JulySeptember.

Turnbull, S. (2008c). The Theory and Practice of Government De-regulation. In J. Choi \& S. DowAnvari, eds, International Finance Review: Institutional approach to global corporate governance, 9, (pp.117-139). Bingley, UK: Emerald Publishing.

Turnbull, S. (2009). Mitigating the exposure of corporate boards to risk and unethical conflicts. In R. W. Kolbe \& D. Schwartz, eds, Corporate Boards: Managers of risk, sources of risk, Chapter 7, (pp. 143-74). Oxford, UK: Blackwell Publishing. 
Turnbull, S. (2010). What's Wrong with Corporate Governance “Best” Practices? In H. K. Baker \& R. Anderson, eds, Corporate Governance: A synthesis of theory research and practice (pp. 79-96).

Hoboken, NJ: John Wiley \& Sons.

Turnbull, S. (2011). Why “Best” Corporate Governance Practices are Unethical and Less

Competitive? In L. Hartman and J. DesJardins, eds. Business Ethics for Personal Integrity and Social Responsibility, $2^{\text {nd }}$ ed. (pp. 576-583). Burr Ridge, IL: McGraw-Hill.

Turnbull, S. (2012). The limitations in corporate governance best practices. In T. Clarke \& D.

Branson, eds. Handbook of Corporate Governance, Chapter 25. London \& Thousand Oaks, CA: Sage.

Turnbull, S. \& Pirson, M. (2012). Could the 2008 US financial crisis been avoided with network governance? International Journal of Disclosure and Governance, Special issue on Financial Crises and Regulatory Responses, 9(1), 1-27.

Vasudev, P.M. \& Watson, S.M. (2012). Corporate Governance after the Financial Crisis. In P.M Vasudev \& Susan Mary Watson, eds, Corporate Governance after the Financial Crisis. Cheltenham, UK: Edward Elgar.

Weiner, N. (1948). Cybernetics: Control and communication in the animal and the machine. New York, NY: John Wiley \& Sons.

Williamson, O.E. (1975). Markets and hierarchies: Analysis and anti-trust implications. New York, NY: Free Press.

Williamson, O.E. (1979). Transaction cost economics: The governance of transactional relations. Journal of Law and Economics, 22, 233-261.

Williamson, O.E. (1985). The economic institutions of capitalism. New York, NY: Free Press

Williamson, O.E. (1990), Industrial organization. London: Gower House.

Zingales L. (2000). In search of new foundations. CRSP Working paper, 515. 